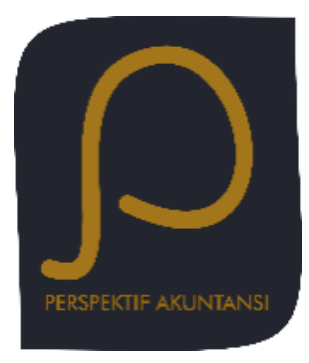

Perspektif Akuntansi

Volume 2 Nomor 1 (Februari 2019), hal. 19-38

ISSN: 2623-0194(Print), 2623-0186(Online)

Copyright $(\subset$ The Authors(s). All Rights Reserved

Fakultas Ekonomika dan Bisnis,

Universitas Kristen Satya Wacana

DOI: https://doi.org/10.24246/persi.v2i1.p19-38

http://ejournal.uksw.edu/persi

\title{
Penciptaan Nilai Pasar oleh Perusahaan Terpercaya
}

\author{
Lenni Yovita ${ }^{1}$ \\ Universitas Dian Nuswantoro \\ Ika Kristianti \\ Universitas Kristen Satya Wacana
}

Received Abstract. The purpose of this study is to test the influence of profitability 20/12/2018 performance (Return on Assets and Return On Equity), Corporate Governance (Corporate Governance Perception Index) on market value

Accepted

$01 / 02 / 2019$ creation (Market Value Added). Using Indonesian listed companies that was ranked in CGPI from 2007 to 2010, the final sample is 40 companies.Based on Multiple Regression Analysis, the empirical resultsshow that profitability performance (ROA) and Corporate Governance (CGPI) are positively significant associated with market value of the firm while profitability performance (ROE) has no effect on market value.This study has several implications: (1)Providing empirical evidence on the process of market value creation and supporting theories which related to value creation, including Signalling Theory, Shareholder Value Creation, and Agency Theory, (2) Showing an application view of the sustainability of market value creation by achieving profitability performance which being target together between shareholder and management, applying Good Corporate Governance.

Keywords: Profitability performance, corporate governance, market value creation

Abstrak. Penelitian ini bertujuan untuk menguji pengaruh kinerja profitabilitas (Return on Assets dan Return On Equity), Corporate Governance (Corporate Governance Perception Index) terhadap

\footnotetext{
${ }^{1}$ lenni.yovita@dsn.dinus.ac.id
} 


\begin{abstract}
penciptaan nilai pasar perusahaan. Penelitian ini menggunakan sampel 40 perusahaan go public di Bursa Efek Indonesia yang masuk dalam pemeringkatan CGPI tahun 2007-2010 pada periode survei tahun 2006-2009. Berdasarkan hasil analisis regresi berganda dengan tingkat signifikansi 5\%, ditemukan bahwa kinerja profitabilitas (ROA) dan Corporate Governance (CGPI) berpengaruh positif signifikan terhadap penciptaaan nilai pasar (MVA growth). Lain halnya dengan hasil ROE yang berpengaruh tidak signifikan terhadap MVA growth. Impikasi studi ini antara lain: (1) memberikan bukti empiris tentang proses penciptaan nilai pasar dan memperkuat teori yang berkaitan dengan penciptaan nilai pasar, yaitu Teori Sinyal, Shareholder Value Creation), dan Teori Keagenan, (2) memberikan gambaran aplikatif penciptaan nilai pasar perusahaan berkesimbungan dengan mencapai kinerja profitabilitas yang menjadi target menjadi target bersama antara pemegang saham dan pihak manajemen, penerapan Good Corporate Governance.
\end{abstract}

Kata kunci: kinerja profitabilitas, tata kelola, tanggung jawab sosial perusahaan, penciptaan nilai pasar

\title{
Pendahuluan
}

Penciptaan nilai pasar perusahaan menjadi fokus perhatian bagi para pengusaha dalam dua dekade terakhir. Hal tersebut terjadi karena telah terjadi persaingan bisnis yang semakin kompetitif di era disruptif. Eksistensi perusahaan hingga puluhan tahun tergantung dari bagaimana perusahaan mampu menciptakan nilai pasar perusahaan. Itulah mengapa tujuan perusahaan berdiri bergeser dari yang hanya semata-mata memaksimalkan profit hingga menjaga keberlangsungan perusahaan (company sustainability). Penciptaan nilai pasar tersebut terkait dengan proses bisnis (business process) suatu perusahaan yang diturunkan ke dalam aktivitas-aktivitas operasionalnya sehingga menghasilkan nilai tambah (value added) dan fokus terhadap penciptaan nilai pasar perusahaan di masa yang akan datang (Glad \& Becker, 2002).

Rappaport (2006) menyarankan beberapa cara untuk menciptakan nilai pemegang saham, yaitu: (1) perusahaan tidak diperbolehkan mengelola laba atau memberikan panduan penghasilan, (2) para pemimpin harus membuat keputusan strategis dan akuisisi serta membawa aset yang memaksimalkan nilai yang diharapkan, bahkan jika pendapatan jangka pendek terkena dampak negatif sebagai hasilnya, (3) perusahaan harus menghindari penggunaan kelebihan uang tunai hanya sekedar untuk membuat investasi yang terlihat baik di permukaan tetapi mungkin akhirnya menghancurkan nilai, seperti akuisisi yang tidak tepat dan mahal, penciptaan nilai akan lebih baik dalam bentuk pengembalian uang tunai kepada pemegang saham dalam bentuk dividen dan pembelian kembali, (4) menetapkan insentif pembayaran yang 
efektif di setiap tingkat manajemen, (5) menekankan bahwa para eksekutif senior harus meletakkan kekayaan mereka di awal seperti yang dilakukan para pemegang saham, (6) mendesak perusahaan untuk menerima pengungkapan penuh, penangkal obsesi laba jangka pendek yang berfungsi untuk mengurangi ketidakpastian investor yang dapat mengurangi biaya modal dan meningkatkan harga saham.

Sebuah konsep atau metode untuk mengukur penciptaan nilai pasar perusahaan adalah Market Value Added (MVA) yang diperkenalkan oleh Steward dan Co pada tahun 1993. Tujuan pengukuran MVA adalah untuk menilai akibat tindakan manajer atas kemakmuran pemegang sahamnya sejak perusahaan tersebut berdiri (Gapenski, 2012). MVA merefleksikan bahwa penciptaan nilai pasar perusahaan sangat memerlukan kejelian manajer perusahaan dalam mengidentifikasi macam aktivitas operasional perusahaan yang efektif dan efisien sehingga bisa menghasilkan profitabilitas perusahaan yang diharapkan oleh pemegang saham.

Para pelaku bisnis hendaknya menyadari bahwa menciptakan kekayaan pemegang saham yang merupakan perwujudan penciptaan nilai bukan lagi sebuah pilihan akan tetapi sebuah keharusan dan poin penting. Seringkali dalam proses penciptaan nilai terjadi konflik kepentingan diantara para pemangku kepentingan (stakeholders). Pemegang saham menghendaki agar selalu ada keuntungan (gain) di setiap investasi akan tetapi para manajer mempunyai kepentingan lain dalam menjalankan perusahaan. Manajer kadang melakukan keputusan manajerial non laba atau keputusan yang tidak mengandung profit. Misalnya, keputusan pemberian hibah atau donasi, sponsorship, dan melakukan tanggung jawab sosial perusahaan.

Peran korporasi sering diperdebatkan sebagai pilihan yang saling eksklusif antara tanggung jawab ekonomi dengan pemegang saham dan tanggung jawab sosial kepada masyarakat (Queen, 2015). Hal ini bisa dijelaskan oleh teori agensi (agency theory) bahwa terdapat hubungan antara pelaku dan agen dalam bisnis. Teori agensi berkepentingan dengan penyelesaian masalah yang dapat terjadi dalam hubungan agensi karena sasaran yang tidak selaras atau tingkat keengganan yang berbeda terhadap risiko. Hubungan agensi yang paling umum dalam keuangan terjadi antara pemegang saham (prinsipal) dan eksekutif perusahaan atau agen (Fama, 1980).

Selain teori agensi, proses penciptaan nilai pasar juga didukung oleh teori sinyal (signalling theory). Teori sinyal menunjukkan bahwa manajer (agen) atau perusahaan memiliki informasi yang secara kualitatif lebih baik daripada orang luar dan mereka menggunakan tindakan atau fasilitas tertentu untuk menyampaikan tentang kualitas perusahaan. Pemegang saham atau investor 
harus menggunakan pengetahuannya untuk menyimpulkan semua kemungkinan sinyal yang ditunjukkan oleh manajer (Leland \& Pyle, 1977).

Berkaitan dengan teori yang mendasari studi ini, beberapa variabel yang mendukung proses penciptaan nilai pasar adalah kinerja profitabilitas dan tata kelola perusahaan yang baik (Latridis, 2013; Ararat, Black, \& Yurtoglu, 2017; Cuñat, Gine, \& Guadalupe, 2012). Kinerja Profitabilitas diukur oleh rasio profitabilitas, antara lain Return on Asset (ROA) dan Return On Equity (ROE) yang dihasilkan oleh perusahaan (Tandelilin, 2010). Sedangkan tata kelola perusahaan (corporate governance) dapat diukur oleh skor CGPI (Corporate Governance Perception Index) yang diterbitkan oleh Majalah SWA. Lembaga pemeringkat tata kelola perusahaan yaitu IICG (The Indonesian Institute For Corporate Governance) melakukan survei terhadap perusahaan-perusahaan yang mempraktikkan tata kelola dan mengolah hasil survei menjadi skor (Siagian, Siregar, \& Rahadian, 2013).

Beberapa studi empiris menggunakan variabel kinerja profitabilitas dan Corporate Governance. Kedua variabel tersebut memiliki keterkaitan ataupun pengaruh signifikan positif terhadap penciptaan nilai perusahaan (Sugiarto, 2002; Griffith, Fogelberg, \& Weeks 2002; Ahmad, 2005; Lefort \& Walker, 2005; Tarjo, 2007; Rogers, 2008; Herawaty, 2008; Amran \& Chalhoub, 2009; Gurbuz, Aybars, \& Kultu, 2010). Akan tetapi beberapa penelitian tidak bisa membuktikan bahwa kinerja profitabilitas atau keuangan dan Corporate Governance tidak terkait atau berpengaruh terhadap penciptaan nilai (Ghazali, 2010; Sanda, Mikailu, \& Garba, 2010).

Berdasarkan latar belakang, maka studi ini hendak menguji: (1) pengaruh kinerja profitabilitas terhadap penciptaaan nilai pasar, (2) pengaruh tata kelola perusahaan (corporate governance) terhadap penciptaan nilai pasar, (3) pengaruh kinerja profitabilitas dan coprorate governance secara simultan terhadap penciptaan nilau pasar. Studi ini bermanfaat yaitu sebagai wacana para pemangku kepentingan perusahaan dalam menjalankan perusahaan dan investor dalam mengambil keputusan berinvestasi.

\section{Telaah Pustaka}

\section{Penciptaan Nilai Pasar Perusahaan}

Penciptaan nilai (value creation) merupakan suatu transformasi dari hasil kreativitas dan inovasi melalui penemuan atau pengembangan dalam menghasilkan produk atau jasa di suatu perusahaan (McKinnon, Gowland, \& Worzel, 2005). Husnan \& Pudjiastuti (2002) menyebutkan bahwa nilai perusahaan merupakan harga yang bersedia dibayar oleh calon pembeli apabila perusahaan tersebut dijual. Semakin tinggi nilai perusahaan, semakin 
besar kemakmuran yang akan diterima oleh pemilik perusahaan. Nilai perusahaan yang dapat memberikan kemakmuran pemegang saham secara maksimum apabila harga saham perusahaan meningkat. Semakin tinggi harga saham, maka makin tinggi kemakmuran pemegang saham (Nurlela, 2008). Untuk mencapai nilai perusahaan umumnya para pemodal menyerahkan pengelolaannya kepada para profesional. Para profesional diposisikan sebagai manajer ataupun komisaris.

Rappaport (2006) menyatakan bahwa beberapa perusahaan domestik dan global yang sedang berkembang telah menunjukkan adanya orientasi nilai pemegang saham. Hal tersebut mengindikasikan bahwa penciptaan nilai menjadi pokok pemikiran bagi perusahaan terkait dengan keberadaan jangka panjang perusahaan sehingga bisa menjaga profit sustainability. Konsep dasar penilaian perusahaan yaitu, nilai ditentukan untuk suatu waktu atau periode tertentu, nilai harus ditentukan pada harga yang wajar, penilaian tidak dipengaruhi oleh kelompok pembeli tertentu.

Secara umum banyak metode dan teknik yang telah dikembangkan dalam penilaian perusahaan, diantaranya adalah: a) pendekatan laba antara lain metode rasio tingkat laba atau Price Earning Ratio, metode kapitalisasi proyeksi laba; b) pendekatan arus kas antara lain metode diskonto arus kas; c) pendekatan dividen antara lain metode pertumbuhan dividen; d) pendekatan aktiva antara lain metode penilaian aktiva; e) pendekatan harga saham; f) pendekatan Economic Value Added (Suharli, 2006). Adapun pendekatan penciptaan nilai bagi pemegang saham juga diidentifikasi oleh Rappaport (2006) yaitu, keunggulan operasional, struktur finansial yang optimal, berfokus, memiliki pertumbuhan laba yang kredibel, informasi atau pengungkapan laporan keuangan yang komunikatif oleh perusahaan dan pembelian saham kembali.

\section{Pengukuran Penciptaan Nilai Pasar Perusahaan}

Stewart \& Co (1993) mengembangkan MVA sebagai alat ukur yang paling pas untuk sukses tidaknya suatu perusahaan dalam menciptakan kekayaan bagi pemilik. MVA mengindikasikan bahwa penciptaan nilai pasar perusahaan sangat memerlukan kejelian manajer perusahaan dalam mengidentifikasi macam aktivitas operasional perusahaan yang efektif dan efisien sehingga bisa menghasilkan profitabilitas perusahaan yang diharapkan oleh pemegang saham (Ramana, 2005; Bayrakdaroglu, Ersoy, \& Citak, 2012). MVA merupakan perbedaan antara nilai pasar dari saham perusahaan dan jumlah modal ekuitas yang telah diberikan oleh pemegang saham. Maka MVA ini harus diminimalkan untuk memaksimalkan kekayaan pemegang saham (Brigham \& Houston, 2015). 


\section{Kinerja Profitabilitas}

Brigham \& Houston (2015) menyatakan bahwa profitabilitas merupakan hasil bersih dari serangkaian kebijakan dan keputusan yang dilakukan oleh perusahaan. Sedangkan kinerja profitabilitas merupakan bagian dari kinerja keuangan yang mengukur efektivitas manajemen dalam menggunakan total aktiva maupun aktiva bersih sebagaimana yang tercatat dalam aktiva dan hasil yang diperoleh melalui usaha manajemen atas dana yang diinvestasikan pemilik (Helfert, 2005).

\section{Pengukuran Kinerja Profitabilitas}

Tandelilin (2010) dalam Analisis Investasi dan Manajemen Portofolio menyebutkan bahwa dari sudut pandang investor, salah satu indikator penting untuk menilai prospek perusahaan di masa yang akan datang adalah dengan melihat sejauh mana pertumbuhan profitabilitas perusahaan. Indikator ini sangat penting diperhatikan untuk mengetahui sejauh mana investasi yang akan dilakukan investor di suatu perusahaan mampu memberikan return yang sesuai dengan tingkat yang disyaratkan investor.

Terkait dengan profitabilitas, maka perusahaan harus mampu menciptakan kinerja profitabilitas dengan formulasi pengurangan biaya. Oleh karena itu, akan digunakan dua rasio profitabilitas utama, yaitu: 1) Return On Equity (ROE) yang menggambarkan sejauh mana kemampuan perusahaan menghasilkan laba yang bisa diperoleh pemegang saham dan 2) Return on Assets (ROA) menggambarkan sejauh mana kemampuan aset-aset yang dimiliki perusahaan bisa menghasilkan laba. Rasio ROE dihitung dengan membagi laba bersih dengan jumlah ekuitas perusahaan. Sedangkan rasio ROA diperoleh dengan membagi laba sebelum bunga dan pajak dengan jumlah aset perusahaan.

\section{Tata Kelola Perusahaan (Corporate Governance)}

Tata kelola perusahaan menurut The Indonesian Institute for Corporate Governance (IICG,2002) merupakan rangkaian mekanisme untuk mengarahkan dan mengendalikan suatu perusahaan agar operasional perusahaan berjalan sesuai dengan harapan para pemangku kepentingan (stakeholders). Tujuan tata kelola adalah untuk memastikan bahwa tujuan kunci pemegang sahammaksimisasi kemakmuran telah diimplementasikan (Brigham \& Daves, 2007). Tata kelola perusahaan juga didukung oleh agency theory yang menyatakan bahwa untuk mengatasi masalah ketidakselarasan kepentingan antara principal dan agent dapat dilakukan melalui pengelolaan perusahaan yang baik (Midiastuty \& Machfoedz, 2003). Lima prinsip dasar Good Corporate Governance (Peraturan Bank Indonesia No. 8/4/PBI/2006) antara lain, Transparency (keterbukaan informasi), Accountability (akuntabilitas), 
Responsibility (pertanggungjawaban), Independency (kemandirian), Fairness (kesetaraan dan kewajaran).

\section{Pengukuran Corporate Governance}

Corporate Governance Perception Index (CGPI) merupakan alat ukur tata kelola perusahaan yang dikembangkan dari IICG melalui survei pada perusahaanperusahaan yang menerapkan tata kelola perusahaan. IICG merupakan lembaga independen yang didirikan pada tanggal 2 Juni 2000 dengan tujuan untuk memasyarakatkan konsep, praktik dan manfaat Good Corporate Governance kepada dunia usaha khususnya dan masyarakat luas pada umumnya.

Kriteria dan acuan yang digunakan IICG dalam memeringkatkan perusahaan terpercaya adalah komitmen terhadap Corporate Governance (15\%); hak pemegang saham dan fungsi kepemilikan kunci (20\%); perlakuan yang setara terhadap seluruh pemegang saham (15\%); peran Stakeholder dalam Corporate Governance (15\%); pengungkapan dan tranparansi (15\%); serta tanggung jawab dewan komisaris dan dewan direksi (20\%).

\section{Shareholder Value Creation Theory}

Teori ini menyatakan bahwa orientasi membangun atau menciptakan nilai pemegang saham perusahaan yang lebih menarik tidak hanya ditujukan kepada para pemegang saham, melainkan juga ditujukan juga untuk karyawan, pelanggan, dan semua pihak-pihak yang berkepentingan (Rappaport, 2006). Rappaport menyebutkan bahwa terdapat insentif pasar yang sangat kuat yang mendorong manajer untuk maksimisasi nilai dalam membuat keputusan yang konsisten dengan hasil yang berdimensi sosial yang dikehendaki yaitu keamanan tempat kerja. Ia juga menjelaskan bahwa manajemen yang dipengaruhi oleh kepentingan pemegang saham akan berinvestasi pada teknologi, pelatihan, atau merekayasa ulang tempat kerja yang mengurangi biaya keamanan.

Pandangan ini menganggap bahwa kunci agar tetap bisa melanjutkan pelayanan pada semua stakeholder perusahaan adalah harus unggul jika mereka ingin tetap bertahan. Lebih lanjut, kelangsungan perusahaan secara jangka panjang tergantung pada hubungan keuangan dari masing-masing stakeholder yang berkepentingan dalam perusahaan. Teori ini juga menyatakan bahwa untuk memenuhi hak atau tuntutan keuangan para stakeholder, manajemen harus menghasilkan aliran kas dengan cara mengoperasikan bisnisnya secara efisien. Tuntutan tesebut akan menekan aliran kas jangka panjang yang isi sebenarnya adalah pendekatan nilai pemegang saham (shareholder value approach). 


\section{Teori Keagenan (Agency Theory)}

Teori keagenan menyatakan bahwa manajemen perusahaan sebagai agen bagi para pemegang saham, akan bertindak sengan penuh kesadaran bagi kepentingannya sendiri, bukan sebagai pihak yang arief dan bijaksana serta adil terhadap pemegang saham (Jensen \& Meckling, 1976). Teori ini menguraikan hubungan antara pihak prinsipal dan agen, prinsipal adalah pihak yang memberikan mandat kepada pihak agen. Prinsipal mendelegasikan tanggung jawab pengambilan keputusan kepada agen dengan hak dan kewajiban kedua belah pihak diuraikan dalam suatu perjanjian kerja yang saling menguntungkan.

Agency Theory tidak menspesifikasikan total kontrol pada agen. Jika berupa total kontrol, kemudian agen tidak leluasa dan perusahaan akan dikuasai seorang diri. Hal yang pokok dari teori agensi adalah bahwa prinsipal mendelegasikan otoritasnya pada agen untuk bertindak atas namanya. Pendelegasian ini memberikan agen peluang membangun utilitasnya pada biaya utilitas prinsipalnya (kekayaan). Teori agensi menspesifikasikan pada kondisi kontrol intermediate, yaitu pertama pendelegasian dan kemudian kontrol untuk meminimalkan potensi penyelewengan pendelegasian (Jensen \& Meckling, 2012).

Dalam teori keagenan, hubungan antara agensi dengan principal dapat terganggu ketika ada perbedaan dalam kepentingan yang akan dicapai. Hubungan yang tidak harmonis antara agen dan principal dapat menyebabkan ketidakseimbangan informasi dalam sebuah perusahaan. Dalam kondisi informasi yang berbeda antara prinsipal dan agen tersebut, dapat mempengaruhi angka-angka dalam laporan keuangan perusahaan. Salah satu cara yang dapat digunakan untuk mengevaluasi atas kejadian asimetri informasi tersebut adalah membatasi perilaku oportunistik manajemen dengan adanya corporate governance.

\section{Teori Sinyal}

Teori sinyal menyatakan bahwa perusahaan memberikan sinyal-sinyal kepada pihak luar perusahaan dengan tujuan untuk meningkatkan nilai perusahaan (Leland \& Pyle, 1977). Isyarat atau sinyal menurut Brigham \& Houston (2002) adalah suatu tindakan yang diambil manajemen perusahaan yang memberi petunjuk bagi investor tentang bagaimana manajemen memandang prospek perusahaan. 


\section{Pengembangan Hipotesis}

\section{Pengaruh Kinerja Profitabilitas Terhadap Penciptaan Nilai Pasar Perusahaan}

Responden pada penelitian Nyiramahoro \& Sooshina (2001) menyatakan bahwa profitabilitas sebagai cara perusahaan yang paling efektif untuk menciptakan nilai bagi para pemegang saham. Begitu juga CEO perusahaan supplier ABB Finlandia, Heinonen (2010) dalam ABB review menyatakan bahwa kinerja profitabilitas bukan hanya sekedar kata-kata yang didengungkan, akan tetapi merupakan inisiatif yang diterapkan secara global yang mampu memberikan nilai kepada pelanggan

Hal tersebut didukung oleh teori shareholder value creation bahwa nilai akan tercipta pada saat perusahaan mampu memberikan return yang sesuai bahkan melebihi ekspektasi shareholder (Rappaport, 1998). Oleh karena itu, manajer akan berpikir bagaimana menciptakan laba maksimum dengan cara efisiensi aktivitas operasi sehingga bisa menciptakan nilai perusahaan.

Analysis of Theoritical Framework, menyatakan bahwa dalam penciptaan nilai pemegang saham, perusahaan disarankan menggunakan alat ukur Economic Value Addes (EVA), Management Value Added (MVA), Cash Value Added (CVA of FWC AB), Cash Value Added by Boston Consulting Group (CVA BCG), DCF, dan $Q$ ratio. Beberapa penelitian menyatakan bahwa kinerja profitabilitas yang diukur dengan Return on Assets berpengaruh positif signifikan terhadap penciptaan nilai pasar (Yuniasih \& Wirakusuma, 2007; Sambora, Handayani, \& Rahayu, 2014; Dewi \& Wirajaya, 2013). Sedikit berbeda dengan ukuran kinerja profitabilitas yang lainnya yaitu Return On Equity yang mengindikasikan arah hubungan positif dengan penciptaan nilai pasar akan tetapi secara statistik tidak signifikan pada level 5\% (Lehn \& Makhija, 1996).

H$_{1}$ : Kinerja profitabilitas (ROA dan ROE) secara positif berpengaruh signifikan terhadap Penciptaan Nilai Pasar Perusahaan (MVA).

\section{Pengaruh Corporate Governance Terhadap Penciptaan Nilai Pasar Perusahaan}

Manfaat Corporate Governance adalah mampu mengatasi kecurangan dan keputusan manajerial yang tidak rasional dan sepihak atau menguntungkan diri sendiri oleh karena adanya supervisi dari pihak independen perusahaan. Korporasi lebih terbuka dalam mengungkapkan struktur finansial perusahaan dalam laporan keuangan. Oleh karena itu, Corporate Governance diharapkan mampu meningkatkan nilai kepercayaan pemegang saham (Newell \& Wilson, 2002). Keberadaan investor institusional dianggap mampu menjadi mekanisme monitoring yang efektif karena investor institusional terlibat dalam 
pengambilan yang strategis sehingga tidak mudah percaya terhadap tindakan manipulasi laba (Bowen, Rajgopal, \& Venkatachalam, 2004; Jensen \& Meckling, 2012). Beberapa penelitian menyatakan bahwa Corporate Governance berpengaruh positif dan secara statistik berpengaruh terhadap nilai pasar (Newell \& Wilson, 2002; Suranta \& Machfoedz, 2003; Tarjo, 2007; Herawaty, 2008; Gurbuz \& Aybars, 2010; Sanda et al., 2010)

$\mathbf{H}_{2}$ : Corporate Governance (CGPI) berpengaruh positif signifikan terhadap Penciptaan Nilai Pasar Perusahaan (MVA).

\section{Metoda}

\section{Sampel Penelitian}

Penelitian ini menggunakan sampel perusahaan go public yang dalam kurun waktu lima tahun (2007-2010) masuk dalam pemeringkatan program CGPI (Corporate Governance Perception Index) sebagai Perusahaan Terpercaya dengan periode survei 2006-2009. Alasan pemilihan sampel perusahaan publik yang masuk dalam pemeringkatan CGPI karena perusahan-perusahaan tersebut telah benar-benar teruji dalam penerapan tata kelola perusahaan (Corporate Governance).

\section{Tabel 1. Seleksi Sampel Penelitian}

\begin{tabular}{lccccc}
\hline \multicolumn{1}{c}{ Kriteria } & Total & \multicolumn{4}{c}{ Rincian Jumlah Perusahaan } \\
\cline { 5 - 7 } & Sampel & 2007 & 2008 & 2009 & 2010 \\
\hline $\begin{array}{l}\text { Perusahaan yang masuk dalam } \\
\text { pemeringkatan CGPI }\end{array}$ & 86 & 25 & 21 & 20 & 20 \\
$\begin{array}{l}\text { Perusahaan non publik (tidak terdaftar di } \\
\text { Bursa Efek Indonesia) }\end{array}$ & $(26)$ & $(6)$ & $(5)$ & $(8)$ & $(7)$ \\
$\begin{array}{l}\text { Perusahaan yang tidak menerbitkan laporan } \\
\text { keuangan lengkap }\end{array}$ & - & - & - & - & - \\
$\begin{array}{l}\text { Perusahaan yang terkena delisting } \\
\text { Perusahaan yang dijadikan sampel }\end{array}$ & - & - & - & - & - \\
Outlier & 60 & 19 & 16 & 12 & 13 \\
\hline Total Sampel & $(22)$ & $(2)$ & $(6)$ & $(10)$ & $(4)$ \\
\hline
\end{tabular}

Sumber: Data sekunder diolah

Tabel 1 merupakan rincian seleksi sampel penelitian. Berdasarkan kriteria seleksi sampel di atas, maka dari 86 perusahaan yang masuk dalam pemeringkatan CGPI pada periode 2007-2010, terdapat 26 perusahaan non publik. Dengan demikian, diperoleh 60 perusahaan yang layak dijadikan sampel. Akan tetapi terdapat pengeluaran sampel sebanyak 22. Dengan demikian, total sampel dalam penelitian ini menjadi 38 perusahaan. Pengeluaran sampel atau outlier disebabkan karena sampel memiliki nilai ekstrim, sehingga harus dihilangkan untuk pengujian hipotesis dalam penelitian ini. 


\section{Variabel Penelitian}

\section{Variabel independen}

Kinerja profitabilitas merupakan bagian dari kinerja keuangan yang mengukur efektivitas manajemen dalam menggunakan total aktiva maupun aktiva bersih sebagaimana yang tercatat dalam aktiva dan hasil yang diperoleh melalui usaha manajemen atas dana yang diinvestasikan pemilik. Oleh karena itu, indikator kinerja profitabilitas adalah Return on Asset (ROA), yaitu mengukur kemampuan perusahaan menggunakan atau mengelola aset-asetnya untuk menghasilkan laba bersih.

$$
\text { ROA }=\frac{\text { Laba bersih setelah pajak }}{\text { Total Aktiva }}
$$

Return On Equity (ROE), yaitu mengukur kemampuan perusahaan menggunakan keseluruhan ekuitas untuk menghasilkan laba bersih.

$$
\mathrm{ROE}=\frac{\text { Laba bersih setelah pajak }}{\text { Ekuitas }}
$$

Tata kelola perusahaan dengan indikator skor CGPI. CGPI adalah instrumen pengukuran tingkat kepercayaan masyarakat terhadap perusahaan yang dikembangkan IICG yang bekerja sama dengan majalah SWA. Kategori skor CGPI adalah (www.swa.co.id): Skor 85-100=Predikat "Sangat Terpercaya"; Skor 70-84= Predikat "Terpercaya"; Skor 55-69=Predikat "Cukup Terpercaya".

\section{Variabel dependen}

Penciptaan nilai pasar yaitu tingkat pengembalian kepada pemegang saham dalam bentuk dividen dan harga saham yang meningkat telah melebihi tingkat risiko pengembalian yang disesuaikan dan disyaratkan oleh pasar saham (Dalborg, 1999).

Indikator penciptaan nilai pasar adalah pertumbuhan MVA, yaitu pertumbuhan rasio selisih dari perbedaan nilai pasar saham dengan modal sendiri yang disetor oleh pemegang saham tahun ini dengan tahun kemarin.

Rumus MVA (Brigham dan Houston, 2002)

MVA growth $=\frac{\operatorname{MVA}(\mathrm{t})-\operatorname{MVA}(\mathrm{t}-1)}{\operatorname{MVA}(\mathrm{t}-1)}$

Keterangan:

MVA $=$ (Jumlah saham beredar $\mathrm{x}$ harga saham $)-$ Total Ekuitas Saham

Biasa

$\operatorname{MVA}(\mathrm{t}) \quad=$ Market Value Added tahun sekarang

MVA ( $\mathrm{t}-1) \quad=$ Market Value Added tahun kemarin 
Kriteria Market Value Added:

a. $\quad$ MVA $>0=$ nilai positif yaitu perusahaan dapat memberikan nilai tambah bagi shareholder

b. MVA $<0=$ nilai negatif yaitu perusahaan tidak dapat memberikan nilai tambah bagi shareholder

\section{Teknik Analisis}

Sampel akan diuji dengan teknik analisis regresi linier berganda dengan aplikasi SPSS. Rangkaian pengujian regresi berganda adalah melakukan uji asumsi klasik terlebih dahulu, meliputi uji normalitas, multikolinieritas, autokorelasi dan heteroskedastisitas. Kemudian dilanjutkan dengan pengujian hipotesis yaitu uji simultan dan uji individual. Uji Simultan F untuk meninjau apakah variabel independen secara kesuluruhan bisa menjelaskan variabel dependen.

Kedua akan dilakukan uji statistik t dalam analisis regresi berganda. Uji parsial t digunakan untuk mengetahui seberapa jauh pengaruh satu variabel independen secara individual dalam menjelaskan variasi variabel dependen. Apabila nilai probabilitas signifikansi $<0.05$, maka suatu variabel independen merupakan penjelas yang signifikan terhadap variabel.

Dengan demikian persamaan regresi linier berganda pada pengujian hipotesis $\mathrm{H}_{1}$ dan $\mathrm{H}_{2}$ adalah:

$\mathrm{MVA}=\beta_{0}+\beta_{1} \mathrm{ROA}+\beta_{2} \mathrm{ROE}+\beta_{3} \mathrm{CGPI}+\mathrm{i}$

Keterangan:

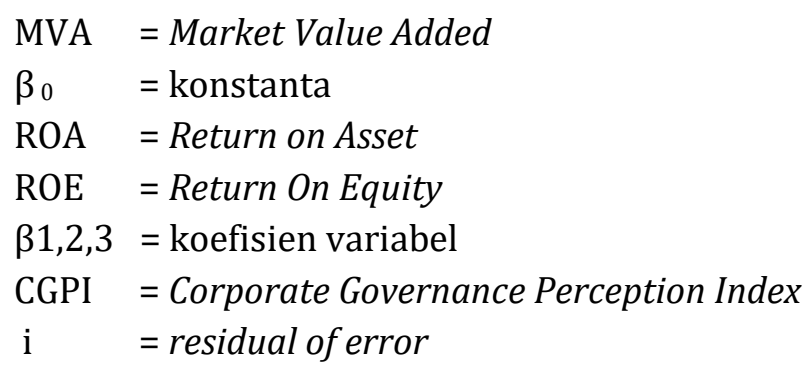

\section{Hasil dan Pembahasan}

\section{Statistik Deskriptif}

Berdasarkan Tabel 2, dapat diketahui bahwa ROA memiliki nilai minimum 0,005 dan nilai maksimum 0,426 serta rata-rata (mean) sebesar 0,087 . Nilai ROA tersebut adalah mewakili kinerja profitabilitas. Dengan demikian, perusahaan rata-rata memiliki efisiensi dalam penggunaan aset untuk memperoleh laba bersih sebesar 8,908\%. 
Tabel 2. Statistik Deskriptif

\begin{tabular}{llllll}
\hline & N & Minimum & Maximum & Mean & Std Deviation \\
\hline ROA & 38 & 0,005 & 0,426 & 0,0873 & 0,089 \\
ROE & 38 & 0,027 & 1,295 & 0,2254 & 0,213 \\
CGPI & 38 & 56,380 & 90,650 & 78,895 & 8,269 \\
MVA growth & 38 & $-0,796$ & 2,675 & 0,6398 & 0,710 \\
\hline
\end{tabular}

Sumber: Data sekunder diolah

Variabel ROE memiliki nilai minimum 0,027 dan nilai maksimum 1,295, serta mean sebesar 0,225. Nilai ROE tersebut mewakili kinerja profitabilitas. Maka dari nilai mean tersebut mengandung arti bahwa perusahaan rata-rata mempunyai efisiensi penggunaan ekuitas untuk memperoleh laba bersih sebesar 22,5 \%. Kemudian, variabel CGPI memiliki nilai minimum 56,380, nilai maksimum 90,650, dan rata-rata (mean) sebesar 78,895, yang berarti bahwa perusahaan sampel yang rata-rata memiliki predikat terpercaya dari kriteria Corporate Governance (skor 70,00-84,99: predikat terpercaya ).

Nilai minimum pertumbuhan MVA sebesar -0,796 dan nilai maksimum sebesar 2,675 serta mean 0,639 dan standar deviasi 0,710. Nilai standar deviasi pertumbuhan MVA yang positif atau lebih dari nol menunjukkan bahwa manajemen perusahaan sampel telah berhasil memberikan nilai tambah kepada para pemegang saham. Nilai MVA yang lebih kecil dari nol dan negatif berarti perusahaan tidak berhasil memberikan nilai tambah kepada para pemegang saham. Dengan demikian, rata-rata perusahaan sampel mampu memberikan nilai tambah bagi investor.

\section{Uji Asumsi Klasik}

Berdasarkan hasil uji normalitas pada Tabel 3, nilai probabilitas KolmogorovSmirnov lebih besar daripada 0,005, yaitu 0,0612, maka dapat dikatakan bahwa data telah terdistribusi normal. Oleh sebab itu, model regeresi dengan sampel 38 perusahaan adalah layak digunakan karena memenuhi asumsi normalitas.

Berikutnya adalah uji multikolinieritas dengan parameter nilai tolerance masing-masing variabel independen adalah > 0,10 dan VIF (Variance Inflation Factor) < 10. Tabel 3, menunjukkan pengujian tersebut menunjukkan tidak ada gejala multikolinearitas antar variabel bebas. Pada panel C, Uji Autokorelasi di Tabel 3 menunjukkan bahwa nilai untuk Durbin-Watson, yaitu 1.792 nilai du pada tabel Durbin-Watson adalah 1.612.Menurut prinsip autokorelasi : du < DW $<4$-du sehingga $1,724<1,831<2,275$ dapat disimpulkan tidak terjadi autokorelasi. 
Tabel 3. Hasil Uji Normalitas, Uji Multikolinearitas, dan Uji Autokorelasi

\begin{tabular}{|c|c|c|c|c|}
\hline \multicolumn{5}{|c|}{ Panel A. Uji Normalitas } \\
\hline \multicolumn{3}{|l|}{ Model } & $\begin{array}{l}\text { Sig.Kolmogorov- } \\
\text { Smirnov }\end{array}$ & Jumlah sampel \\
\hline \multicolumn{3}{|c|}{$\begin{array}{l}\text { MVA }=\beta_{0}+\beta_{1} \mathrm{ROA}+\beta_{2} \mathrm{ROE}+ \\
\beta_{3} \mathrm{CGPI}\end{array}$} & 0,612 & 38 \\
\hline \multicolumn{5}{|c|}{ Panel B. Uji Multikolinieritas } \\
\hline Variabel & Tolerance & VIF & \multicolumn{2}{|c|}{ Kesimpulan } \\
\hline ROA & 0,865 & 1,157 & \multicolumn{2}{|c|}{ Tidak ada multikolinearitas } \\
\hline ROE & 0,863 & 1,159 & \multicolumn{2}{|c|}{ Tidak ada multikolinearitas } \\
\hline CGPI & 0,990 & 1,010 & \multicolumn{2}{|c|}{ Tidak ada multikolinearitas } \\
\hline \multicolumn{5}{|c|}{ Panel C. Uji Autokorelasi } \\
\hline $\mathrm{Du}$ & DW & 4-DU & \multicolumn{2}{|l|}{ Kesimpulan } \\
\hline 1,612 & 1,792 & 2,388 & \multicolumn{2}{|c|}{ Tidak ada autokorelasi } \\
\hline
\end{tabular}

Sumber: Data sekunder diolah

Uji berikutnya adalah pengujian heteroskedastisitas. Pengujian akan dilakukan dengan melihat grafik scatterplot antara residu variabel dependen SRESID dengan nilai prediksi variabel Independen ZPRED. Deteksi keberadaan heteroskedastisitas dapat diimplementasikan dengan melihat ada dan tidaknya pola tertentu pada grafik antara SRESID dan ZPRED, Y adalah nilai residual dan $\mathrm{X}$ adalah nilai yang telah prediksi. Di bawah ini merupakan scatterplot dalam pengujian heteroskedastisitas:

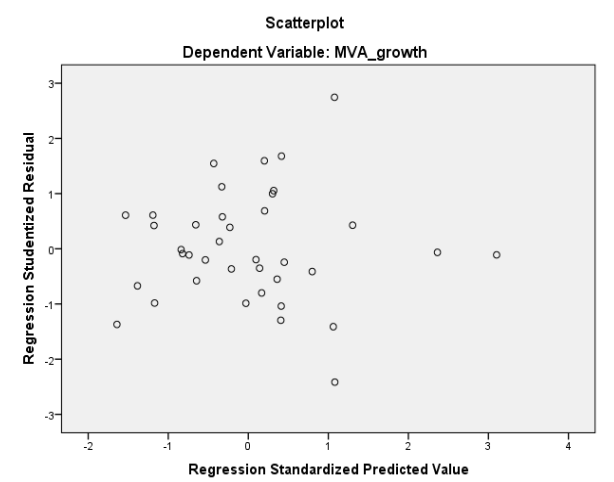

\section{Grafik 1. Hasil Pengujian Heteroskedastisitas}

Berdasarkan Grafik 1, dapat diketahui bahwa tidak ada pola yang jelas, titik menyebar di atas dan di bawah angka nol pada sumbu Y, dengan demikian tidak terjadi heteroskedastisitas.

\section{Tabel 4. Hasil Uji F Dan Koefisien Determinasi}

\begin{tabular}{llllll}
\hline Panel A. Hasil Uji F & \multicolumn{5}{l}{} \\
\hline Model & Sum of Squares & Df & $\begin{array}{l}\text { Mean } \\
\text { Square }\end{array}$ & F & Signifikansi \\
Regression & 6,767 & 3 & 2,256 & 6,435 & 0,001 \\
Residual & 11,917 & 34 & 0,350 & & \\
Total & 18,684 & 37 & & & \\
\hline
\end{tabular}




\begin{tabular}{|c|c|c|c|}
\hline \multicolumn{4}{|l|}{ Panel B. Koefisien Determinasi } \\
\hline Model & $\mathrm{R}$ & R Square & Adjusted R Square \\
\hline $\begin{array}{l}\mathrm{MVA}=\beta_{0}+\beta_{1} \mathrm{ROA}+\beta_{2} \mathrm{ROE}+ \\
\beta_{3} \mathrm{CGPI}\end{array}$ & 0,602 & 0,362 & 0,306 \\
\hline \multicolumn{4}{|l|}{ Sumber: Data sekunder diolah } \\
\hline \multicolumn{4}{|c|}{$\begin{array}{l}\text { Pada Panel A Tabel } 4 \text {, dapat diketahui bahwa nilai signifikansi } 0,001 \text {. Oleh } \\
\text { karena signifikansi lebih kecil dari } 0.05 \text { berarti kinerja profitabilitas dan } \\
\text { Corporate Governance secara simultan berpengaruh signifikan terhadap } \\
\text { penciptaan nilai pasar. Lebih lanjut, koefisien determinasi ditunjukkan oleh } \\
\text { adjusted } R \text { square sebesar } 0,362 \text {. Hal tersebut menunjukkan bahwa variabel } \\
\text { dependen yaitu penciptaan nilai pasar (MVA) dapat dijelaskan secara signifikan } \\
\text { oleh variabel independen ROA, ROE, CGPI sebesar } 36,20 \% \text { sedangkan } 63,80 \% \\
\text { dijelaskan oleh faktor lain. }\end{array}$} \\
\hline
\end{tabular}

\section{Pengaruh Kinerja Profitabilitas Terhadap Penciptaan Nilai Pasar Perusahaan}

Tabel 5 menyajikan hasil pengujian Hipotesis $1\left(\mathrm{H}_{1}\right)$ dengan analisis regresi berganda:

Tabel 5. Hasil Pengujian Hipotesis 1

\begin{tabular}{ccccc}
\hline & $\begin{array}{c}\text { Koefisien } \\
\text { Variabel } \\
\text { (Beta) }\end{array}$ & $\begin{array}{c}\text { Nilai T } \\
\text { hitung }\end{array}$ & $\begin{array}{c}\text { Signifikansi } \\
\text { (Nilai } \\
\text { Probabilitas) }\end{array}$ & Kesimpulan \\
\hline Constant $\left(\beta_{0}\right)$ & $-2,437$ & $-2,581$ & & - \\
$\operatorname{ROA}\left(\beta_{1}\right)$ & 0.392 & 2.659 & 0.012 & Mendukung $\mathrm{H}_{1}$ \\
$\operatorname{ROE}\left(\beta_{2}\right)$ & 0.138 & 0.939 & 0.354 & Tidak Mendukung $\mathrm{H}_{1}$ \\
\hline
\end{tabular}

Sumber: Data sekunder diolah

Pada Tabel 5, nilai signifikansi 0,012 bermakna bahwa ROA berpengaruh positif terhadap penciptaan nilai pasar perusahaan (MVA) dan secara statistik signifikan pada level 5\%. Sedangkan nilai signifikansi ROE sebesar 0.354 , menunjukkan bahwa ROE tidak berpengaruh terhadap nilai pasar perusahaan (MVA) pada level 5\%.

Hasil pengujian Hipotesis 1 mendukung penelitian sebelumnya (Carlson \& Bathala, 1997; Yuniasih \& Wirakusuma, 2007; Lehn \& Makhija, 1996; Sambora et al., 2014; Dewi \& Wirajaya, 2013), yaitu ROA berpengaruh positif signifikan terhadap nilai pasar dan kapitalisasi asar sedangkan ROE tidak signifikan berpengaruh terhadap nilai pasar yang diukur dengan Tobin's Q . Hasil penelitian ini juga konsisten dengan penelitian sebelumnya yaitu profitabilitas merupakan cara perusahaan yang paling efektif untuk menciptakan nilai bagi para pemegang saham (Nyiramahoro \& Sooshina, 2002).

Selain hasil tersebut, hasil penelitian ini juga memperkuat beberapa teori , yaitu: (1) teori Shareholder Value Creation (Rappaport, 2006), yaitu nilai akan 
tercipta pada saat perusahaan mampu memberikan return yang sesuai bahkan melebihi ekspektasi pemegang saham, sehingga manajer akan berpikir bagaimana cara mencapai laba maksimum guna menciptakan nilai perusahaan dengan cara efisiensi aktivitas operasi, (2) Teori Sinyal menurut Leland \& Pyle (1977) bahwa kinerja profitabilitas akan memberikan sinyal yang positif bagi investor untuk melakukan tindakan rasionalitas dalam berinvestasi. Return on Assets juga merupakan hal yang mendasar bagi terciptanya nilai pasar karena dari keefektifan penggunaan total aktiva akan mempengaruhi laba yang berkelanjutan. Pasar atau investor akan sangat tertarik apabila perusahaan mampu mencetak laba lebih besar dari yang diperkirakan investor. Perusahaan dinilai akan mampu memberikan keuntungan baginya atau bisa memaksimalkan nilai pemegang saham.

Lebih lanjut, hasil pengujian indikator ROE sejalan dengan artikel Harm (2017) bahwa memaksimalkan nilai pemegang saham tidak hanya melalui maksimisasi ROE akan tetapi harus didukung dengan strategi maksimisasi nilai. Hasil pengujian dengan indikator ROE juga mendukung pernyataan yang dikemukakan oleh Brigham \& Houston (2010) bahwa terdapat beberapa masalah yang timbul ketika perusahaan menggunakan ROE sebagai ukuran kinerja untuk memaksimalkan kekayaan pemegang saham, diantaranya: ROE tidak mempertimbangkan risiko, sedangkan pemegang saham selain memperhatikan pengembalian juga jelas memperhatikan risiko, ROE tidak mempertimbangkan jumlah modal yang telah diinvestasikan, ROE menjadi ukuran yang tidak relevan dalam perhitungan bonus akhir tahun karena tidak memperhitungkan biaya modal sebuah investasi. Pengembalian berbanding lurus dengan risiko dan biaya modal. Semakin tinggi pengembalian yang diminta investor, maka semakin tinggi risiko karena perusahaan akan menempatkan pada instrumen investasi yang bernilai tinggi dan secara otomatis biaya modal juga tinggi.

Knight (1998) mengatakan bahwa profitabilitas yang lebih tinggi tidak menjamin pencipataan nilai pemegang saham dalam sebuah perusahaan. Clarke (2000) menegaskan bahwa yang terpenting dalam penciptaan nilai pasar adalah konsistensi perushaaan terhadap prinsip nilai pemegang saham yang terfokus pada aliran kas daripada sekedar laba.

Selain itu, data time series penelitian ini adalah tahun 2006-2009. Seperti yang telah kita ketahui bahwa terjadi gejolak finansial di tahun 2008 karena krisis keuangan dunia dan pemulihan di tahun 2009. Beberapa perusahaan sampel menghadapi permasalahan dengan ekuitas perusahaan sehubungan dengan gejolak di bursa. Harga saham yang terus menerus turun menyebabkan kapitalisasi pasar perusahaan menjadi tidak stabil. Padahal kapitalisasi pasar 
perusahaan merupakan bagian dari total ekuitas untuk menghitung Return On Equity (ROE).

\section{Pengaruh Corporate Governance Terhadap Penciptaan Nilai Pasar Perusahaan}

Pada Tabel 6, hasil pengujian $\mathrm{H}_{2}$ dengan analisis regresi berganda menunjukkan nilai signifikansi 0.007 mempunyai makna bahwa bahwa Corporate Governance (CGPI) secara positif berpengaruh signifikan terhadap nilai pasar perusahaan (MVA). Hasil studi ini membuktikan bahwa penerapan Corporate Governance tidak sekedar laporan teoritis pada laporan keuangan perusahaan-perusahaan terpercaya. Akan tetapi, hal ini telah menjadi praktik umum, sehingga para pemegang saham memberikan kepercayaan penuh untuk mengembangkan kekayaannya.

Tabel 6. Hasil Pengujian Hipotesis 2

\begin{tabular}{lcccc}
\hline & $\begin{array}{c}\text { Koefisien } \\
\text { Variabel (Beta) }\end{array}$ & Nilai T hitung & $\begin{array}{c}\text { Signifikansi } \\
\text { (Nilai Probabilitas) }\end{array}$ & Kesimpulan \\
\hline Constant $\left(\boldsymbol{\beta}_{\mathbf{0}}\right)$ & $-2,437$ & $-2,581$ & & - \\
CGPI $\left(\boldsymbol{\beta}_{3}\right)$ & 0.034 & 0.012 & 0.007 & Mendukung $\mathrm{H}_{2}$ \\
\hline
\end{tabular}

Sumber: Data sekunder diolah

Hasil pengujian $\mathrm{H}_{2}$ juga mendukung teori sinyal (Leland \& Pyle, 1977) yaitu Corporate Governance merupakan sinyal positif terhadap nilai pasar dan juga beberapa penelitian sebelumnya yang menyatakan Corporate Governance berpengaruh positif terhadap nilai pasar (Newell \& Wilson, 2002; Suranta \& Machfoedz, 2003; Tarjo, 2007; Herawaty, 2008; Gurbuz \& Aybars, 2010; Sanda et al., 2010)

\section{Simpulan}

Berdasarkan pada hasil analisis dan pembahasan, maka kesimpulan dari penelitian ini adalah kinerja profitabilitas yang diukur dengan Return on Assets (ROA) berpengaruh positif dan secara statistik berpengaruh terhadap penciptaan nilai pasar perusahaan (Market Value Added). Sebaliknya, indikator kinerja profitabilitas yang lainnya, yaitu Return On Equity (ROE) walau menunjukkan arah positif akan tetapi secara statistik tidak berpengaruh signifikan terhadap MVA. Pasar bereaksi bahwa memaksimalkan nilai pemegang saham tidak hanya melalui maksimisasi ROE akan tetapi harus didukung dengan strategi maksimisasi nilai. Corporate Governance yang diukur dengan skor CGPI (Corporate Governance Perception Index) tidak berpengaruh signifikan terhadap penciptaan nilai pasar perusahaan (Market Value Added).

Keterbatasan dalam penelitian ini adalah periode penelitian yang dalam jangka waktu pendek. Untuk penelitian mendatang perlu adanya pertimbangan 
periode pengamatan yang lebh lama serta dari berbagai jenis industri perusahaan. Implikasi bagi perusahaan adalah perusahaan dapat mengukur kinerja profitabilitas dari dua rasio yaitu ROA dan ROE. Dalam penciptaan nilai perusahaan yang tinggi, yang perlu diperhatikan adalah ROA karena secara statistik berpegaruh secara signifikan.

\section{Daftar Pustaka}

Amran, N. A., \& Ahmad, A. Che (2016). Effects of Ownership Structure on Malaysian Companies Performance. Asian Journal of Accounting and Governance, 4(1), 5160. https://doi.org/10.17576/ajag-2013-4-5774

Ararat, M., Black, B. S., \& Yurtoglu, B. B. (2017). The effect of corporate governance on firm value and profitability: Time-series evidence from Turkey. Emerging Markets Review. https://doi.org/10.1016/j.ememar.2016.10.001

Bayrakdaroglu, A., Ersoy, E., \& Citak, L. (2012). Is there a relationship between corporate governance and value-based financial performance measures? A study of Turkey as an emerging market. Asia-Pacific Journal of Financial Studies. https://doi.org/10.1111/j.2041-6156.2012.01071.x

Bowen, R. M., Rajgopal, S., \& Venkatachalam, M. (2004). Accounting Discretion, Corporate Governance and Firm Performance. SSRN. https://doi.org/10.1506/car.25.2.4

Brigham, E. F., \& Daves, P. R. (2007). Capital Budgeting: Decision Criteria. In Intermediate Financial management. https://doi.org/10.1016/08908389(89)90100-5

Carlson, S. J., \& Bathala, C. T. (1997). Ownership differences and firms' income smoothing behavior. Journal of Business Finance and Accounting. https://doi.org/10.1111/1468-5957.00101

Chalhoub, M. (2009). Relations between Dimensions of Corporate Governance and Corporate Performance: An Empirical Study among Banks in the Lebanon. International Journal of Management, 26, 476-488. http://proquest.umi.com/pqdweb?did=1889954381\&Fmt=7\&clientId=2653 3\&RQT $=309 \&$ VName $=P Q$

Clarke, Peter . (2000). Shareholder Value: article. Dublin, Ireland

Cuñat, V., Gine, M., \& Guadalupe, M. (2012). The vote is cast: The effect of corporate governance on shareholder value. Journal of Finance. https://doi.org/10.1111/j.1540-6261.2012.01776.x

Dalborg H. (1999), Shareholder value in banking, paper prepared for the May 1999 session of Institrut International d'Etudes Bancarie.

Dewi, A. S. M., \& Wirajaya, A. (2013). Pengaruh Struktur Modal, Profitabilitas, dan Ukuran Perusahaan pada Nilai Perusahaan. E-Jurnal Akuntansi. https://doi.org/ISSN : 2302-8556

Brigham, Eugene F. \& Houston, Joel F. (2015). Fundamentals of Financial Management. Cengage Learning. https://doi.org/10.1016/0377-841X(78)90069-4

Fama, E. F. (1980). Agency Problems and the Theory of the Firm Agency Problems and the Theory of the Firm. The Journal of Political Economy. https://doi.org/10.1086/260866

Gapenski, L. C. (2012). Healthcare Finance: An introduction to accounting and finacnial management; Operating indicator ratios. In Healthcare finance, An introduction to accounting and financial management, 5th ed. 
Ghazali, N. A. M. (2010). Ownership structure, corporate governance and corporate performance in Malaysia. International Journal of Commerce and Management. https://doi.org/10.1108/10569211011057245

Glad, E., Becker, H. (2002). Activity-Based Costing and Management, John Willey and Sons, ISBN 0-471-96331-3

Griffith, J. M., Fogelberg, L., \& Weeks, H. S. (2002). CEO ownership, corporate control, and bank performance. Journal of Economics and Finance, 26(2), 170-183. https://doi.org/10.1007/BF02755984

Gurbuz, A. 0., \& Aybars, A. (2010). The Impact of Foreign Ownership on Firm Performance, Evidence from an Emerging Market: Turkey. American Journal of Economics and Business Administration. https://doi.org/10.3844/ajebasp.2010.350.359

Harm, Travis W . (2017). Basic of Finance Statement Analysis. A Guide for Private Company Directors and Shareholders. https://mercercapital.com/assets/Article_Financial-Statement-AnalysisBasics-2017.pdf

Helfert, Erich A. (2005). Techniques Of Financial Analysis. Richard D Irwin.Inc

Herawaty, V. (2008). Peran Praktek Corporate Governance Sebagai Moderating Variable dari Pengaruh Earnings Management Terhadap Nilai Perusahaan. Jurnal Akuntansi Dan Keuangan. https://doi.org/10.3390/ncrna4030018

Husnan, Suad \& Pudjiastuti, Enny (2002). Dasar-Dasar Manajemen Keuangan. Yogyakarta: UPP AMP YKPN

Jarmo, Heinonen.(2010).Operational Excellence-Ensuring Consistant,High Quality Service Delivery in Process Automation. Finland: ABB Review

Jensen, M. C., \& Meckling, W. H. (1976). Theory of The Firm: Managerial Behavior, Agency Costs, and Ownership Structure. Journal of Financial Economics.

Jensen, M., \& Meckling, W. (2012). Theory of the firm: Managerial behavior, agency costs, and ownership structure. In The Economic Nature of the Firm: A Reader, Third Edition. https://doi.org/10.1017/CB09780511817410.023

Knight, James, A. (1998). Value Based Management: Developing a Systematic Approach to Creaing Shareholder Value. New York, USA: McGraw-Hill

Latridis, G. (2013). IFRS Adoption and Financial Statement Effects : The UK Case. International Research Journal of Finance and Economics.

Lefort, F., \& Walker, E. (2005). The Effect of Corporate Governance Practices on Company Market Valuation and Payout Policy in Chile. SSRN. https://doi.org/10.2139/ssrn.676710

Lehn, K., \& Makhija, A. K. (1996). EVA \& MVA as performance measures and signals for strategic change. Strategy \& Leadership. https://doi.org/10.1108/eb054556

Leland, H. E., \& Pyle, D. H. (1977). Informational Asymmetries, Financial Structure, and Financial Intermediation. The Journal of Finance. https://doi.org/10.2307/2326770

McKinnon, R., Gowland, C., \& Worzel, K. (2005). From breakthrough to value creation. Mastering profitable discovery. Strategy and Leadership. https://doi.org/10.1108/10878570510594415

Midiastuty, P. P., \& Machfoedz, M. (2003). Analisis Hubungan Mekanisme Corporate Governance dan Indikasi Manajemen Laba. Makalah Simposium Nasional Akuntansi VI. https://doi.org/10.1017/CB09781107415324.004

Newell, R., \& Wilson, G. (2002). Corporate Governance: A Premium for Good Governance. The McKinsey Quarterly.

Nurlela, Rika. (2008). Pengaruh Corporate Social Responsibility Terhadap Nilai Perusahaan Dengan Prosentrase Kepemilikan Manajemen Sebagai Variabel Moderating (Studi Empiris Pada Perusahaan Yang Terdaftar di Bursa Efek 
Jakarta. Journal Universitas Syiah Kuala. https://doi.org/10.1016/j.watres.2016.05.075

Nyiramahoro, B., \& Shoosina, N. (2001). Creating and Measuring Shareholder Value, Applicability and Relevance in Selected Swedish Companies, International Accounting and Finance Master Thesis, Gotheborg University.

Queen, P.E. (2015). Enlightened Shareholder Maximization: Is this Strategy Achievable? Journal of Business Ethics. https://doi.org/10.1007/s10551-014-2070-6

Ramana, D. V. (2005). Market Value Added and Economic Value Added: Some Empirical Evidences. SSRN. https://doi.org/10.2139/ssrn.871404

Rappaport, A. (2006). 10 ways create shareholder value. Harvard Business Review.

Rogers, M. (2008). Corporate Governance and Financial Performance of Selected Commercial Banks in Uganda. In Corporate Responsibility Research Conference (CRRC) (pp. 1-18). Queen's University Belfast. Retrieved from http://www.crrconference.org/

Sambora, M. N., Handayani, S. R., \& Rahayu, S. M. (2014). Pengaruh Leverage Dan Profitabilitas Terhadap Nilai Perusahaan (Studi pada Perusahaan Food and Beverages yang terdaftar di BEI periode tahun 2009 - 2012). Jurnal Administrasi Bisnis. https://doi.org/10.1017/CB09781107415324.004

Sanda, A. U., Mikailu, A. S., \& Garba, T. (2010). Corporate governance mechanisms and firms' financial performance in Nigeria. Afro-Asian J. of Finance and Accounting. https://doi.org/10.1504/AAJFA.2010.035193

Siagian, F., Siregar, S. V., \& Rahadian, Y. (2013). Corporate governance, reporting quality, and firm value: evidence from Indonesia. Journal of Accounting in Emerging Economies. https://doi.org/10.1108/20440831311287673

Stewart, Bennett G III (1993). The Ques For Value. Harper Business, USA

Sugiarto, M. (2002). Pengaruh struktur kepemilikan dan kebijakan dividen terhadap nilai perusahaan dengan kebijakan hutang sebagai intervening. Jurnal Akuntansi Kontemporer, 3(I), 1-26.

Suharli, M. (2006). Studi Empiris Mengenai Pengaruh Profitabilitas,Leverage, dan Harga Saham terhadap Jumlah Dividen Tunai (Studi pada perusahaan yang terdaftar di Bursa Efek Jakarta periode 2002-2003). Jurnal Universitas Katolik Indonesia Atma Jaya. https://doi.org/10.1016/j.energy.2016.04.095

Suranta, E., \& Machfoedz, M. (2003). Analisis Struktur Kepemilikan, Nilai Perusahaan, Investasi, dan Dewan Direksi. Simposium Nasional Akuntansi VI. https://doi.org/10.1002/pssb.2220560234

Tandelilin, E. (2010). Dasar-dasar Manajemen Investasi. Keuangan.

Tarjo. (2007). Pengaruh Konsentrasi Kepemilikan Institusional Dan Leverage Terhadap Manajemen Laba, Nilai Pemegang Saham Serta Cost. Journal of Experimental Psychology: General. https://doi.org/10.1017/CB09781107415324.004

Yuniasih, N. W., \& Wirakusuma, M. G. (2007). Pengaruh Kinerja Keuangan Terhadap Nilai Perusahaan Dengan Pengungkapan Corporate Social Responsibility Sebagai Variabel Pemoderasi. Jurnal Ilmiah Akuntansi Dan Bisnis. https://doi.org/10.1017/CB09781107415324.004 